\title{
Sweden: The times are a-changing
}

ONCE every three years, the Swedish government publishes a bill setting out its future priorities for science. The last one, produced at the beginning of 1990 , anticipated a period of rising research budgets and expressed a desire for "continuity and renewal" in relation to the policies of the previous decade.

The next one, due to be published in February, promises to be radically different. For one thing, the Swedish economy has since plunged into crisis. For another, the government has changed political complexion, and the Social Democrat ideology which permeated thinking about science and technology during most of the $1980 \mathrm{~s}$, and indeed the post-war period in general, has given way to a neo-liberalism that emphasizes the primacy of the market and the desirability of cutting public expenditure.

At present, Swedish scientists have little to complain about. Sweden still spends almost 3 per cent of its gross national product (GNP) on research and development - a figure that puts it with Japan, Germany and the United States at the top of the list of countries belonging to the OECD. Despite the country's economic difficulties, basic research has so far escaped virtually unscathed, and this year's budget for the research councils is likely to remain at roughly the same level as last year's. Furthermore, Sweden still dominates Nordic science, both in terms of the money it spends and the quality of the science it produces.

But some cracks in the edifice are beginning to show. At the end of the 1980 s, after a period in which it had been growing at more than 10 per cent a year, research spending by the private sector began to fall. Although government funding for research continued to increase, the result was still an unprecedented drop in the country's total R\&D spending from 3.04 per cent of the GNP in 1987 to an estimated 2.54 per cent last year.

The government claims that the complex structures established to support research and development in the past in particular the idea that applied research should be heavily supported by public funds and carried out primarily in universities - are no longer appropriate to the new competitive environment of the 1990s.

It is now arguing the case for centres of excellence in universities and for extra funding to be given to university research groups prepared to orient their activities towards the interests of Swedish industry; in short, for more explicit selectivity and élitism.

"We are saying that competition and élitism are good for science", says Håkon Eriksson, professor of reproductive endocrinology at the Karolinska Institute in Stockholm, deputy secretary of the Medical Research Council, and secretary of a committee set up by the government to prepare a new science policy. "In a country like Sweden, to come out and say we support élitism and should put special resources into centres of excellence is something completely new; even if people had thought it, they had not dared to say it."

The modern system of $R \& D$ funding has grown hand-in-hand with the expansion of the country's welfare state. In particular, the rapid expansion in the 1950 s and 1960s of the Swedish infrastructure, including power supplies, telecommunications and health services, provided both industry and the academic community with an important source of research funds (and formed the basis on which Swedish industry was able to make its substantial achievements in high technology).

It is this "Swedish model" of research and development that is being actively rejected by the new government. "There is now a contraction in the public sector, and heavy investment by the government is therefore not as important as it has been for Swedish industry," says Bjarne Kirsebom, under-secretary of state in the Ministry of Education and Science.

Exploring new ways of boosting industrial research without involving heavy public subsidies has been one of the priorities facing the new Minister for Education and Science, Per Unckel.

One goal that the government has already adopted is to double the number of PhDs produced in technical subjects by the end of the century. The hope here is that when these postgraduates move into industry, they will become the research "purchasers" of tomorrow.

Other goals will be presented in the bill that the government will submit to parliament in February, setting out the main guidelines for its proposed science policy over the three years 1993-96. The details are still being vigorously debated. But some preliminary ideas of the directions in which it is likely to point have already been published by the government in a recent discussion document.

Not surprisingly, the document has a strong neo-liberal flavour. It summarizes the overriding aim of the government's proposed strategy as being "to contribute towards the creation of long-term opportunities for a competitive Swedish knowledge environment", and takes a dig at previous government policies by stating a "general rule" that "research of outstanding quality cannot be planned into existence by direct political means."

Some of its detailed proposals have already been controversial. For example, the document suggests that too much money may be going into agricultural research, and that a transfer of funds to other research fields might be "amply justified".

More widely debated has been the strong emphasis being placed on the need to build links with industry. "Universities have a key role as independent generators of knowledge, but we have to look on that knowledge as a key resource for society, and we have to improve that transfer of that knowledge to society", says Eriksson.

For some, however, such remarks suggest that the government is in danger of neglecting the specific needs of basic research by emphasizing what one scientist describes as "applied science for today's industry, not the basic research for tomorrow's".

Others are more concerned that, despite all its enthusiasm for closer links between industry and universities, the government has so far given little concrete indication of how it intends in practice to achieve this while reducing the use of public funds.

Much uncertainty, for example, hangs over the fate of the National Board for Industrial and Technical Development (NUTEK), the successor to the National Technology Board (STU). In the 1980s, STU played a key role in supporting technological research in universities in areas considered important to the country's future.

NUTEK is asking for a considerable increase in funding next year, much of which would be used to set up universitybased "centres of competence" in areas of strategic industrial interest. The government has indicated that it is sympathetic to the content of NUTEK's request. But it still appears uncertain about how far its principles will allow it to go in committing public funds to support the interests of private industry.

The government's final decision on this point, as on others "still under negotiation", will not become known until budget figures are published in the science policy bill. "This is going to be probably the most interesting science bill we have had for many years," says Rikard Stankiewitz of the Research Policy Institute at the University of Lund. "There will be real change. But exactly what they will be - and whether they will be for good or ill - we will not know until we have seen the figures." 